Kinestetik : Jurnal Ilmiah Pendidikan Jasmani 5 (2) (2021)

Kinestetik : Jurnal Ilmiah Pendidikan Jasmani

https://ejournal.unib.ac.id/index.php/kinestetik/index

DOI : 10.33369/jk.v5i2.17786

\title{
THE EFFECT OF UP AND DOWN STANDARD EXERCISE ON THE RESULTS OF THE SQUAT STYLE LOP ON EXTRACURRICULAR PARTICIPANTS OF SMA NEGERI 6 SOUTH BENGKULU
}

\section{Syafrial $^{1}$, Arwin ${ }^{2}$, Rati Marya Kontesa ${ }^{3}$,}

${ }^{123}$ Physical Education Study Program, FKIP, Bengkulu University, Bengkulu City, Indonesia

\section{Article Info}

Article History :

Received :June 2021

Revised : June 2021

Accepted : June 2021

Available online: June 2021

\section{Keywords:}

Up And Down Stairs, Long Jump, Squat Style

\begin{abstract}
This research purpose to know the influence practice up and down stairs to result long jump style squat, this research was conduct on the square SMA Negeri 6 Bengkulu Selatan.in student follow extracullicular long jump, this study uses an experimental method, the design used is the design of one group pretest-posttest, that is pretest before given treatment and posttest after being treated. the treatment given there is one exercise up and down stairs. Data collection techniques in this study with the direct test method that is using the long jump, statistical prerequite tests meet 5 homogeneous requirements and normally distribute data based on statistical calculations obtained from the data count $=5.664>T_{-}($table $=$) 2.064 with the level $=0.05$. The result of this study indicates on the ability of the extracurricular SMA Negeri 6 Bemgkulu Selatan.
\end{abstract}

Corresponding address: Jl. Raden Fatah No. 100, Bengkulu City

*Corresponding email: Syafrial@unib.ac.id
ISSN 2685-6514 (Online)

ISSN 2477-331X (Print) 


\section{INTRODUCTION}

Athletics is one of the most complex sports, because many numbers are competed in this branch such as walking, running, jumping and throwing. In addition, the movements contained in athletics are the basic movements for other sports, because almost all sports require strength, speed, flexibility, and endurance. Athletics sports contain educative values that play an important role in developing physical conditions and can develop self-confidence, discipline, sportsmanship, and courage. So to support learning objectives, According to the regulation of the minister of education and culture of the Republic of Indonesia number 62 of 2014 concerning extracurricular activities in elementary to high school education. Article 1 number 1 means: extracurricular activities are curricular activities carried out by students outside of learning hours for intracurricular activities and extracurricular activities. and Article 2 which is meant by extracurricular activities organized with the aim of developing the potential, talents, interests, abilities, personality, cooperation, and independence of students optimally.

$$
\text { Researchers conducted }
$$

observations at SMA Negeri 6 Bengkulu Selatan. To see how the extracurricular activities implemented by the teacher or coach of the athletic extracurricular activities were carried out. The available facilities and infrastructure did not escape the observations of the researchers. Then the researchers also looked at the completeness of the facilities and infrastructure as well as the role of the trainer and the training methods were categorized as good or not.
From observations made by researchers at SMA Negeri 6 Bengkulu Selatan, which is often experienced by students participating in extracurricular athletics, especially the long jump, is very lacking, because the teacher teaches the long jump without using exercise. So that many students cannot do a good and correct long jump squat style. Therefore, based on this problem, the writer is motivated to provide an exercise to improve the long jump results. Based on observations and several long jump learning experiences so far, students make mistakes during repulsion and lack of power during repulsion.

The results of the author's observations in participating in the field experience program at SMA Negeri 6 Bengkulu Selatan, in learning and athletic training in the squat style long jump branch in power, speed and power training are still low. While power training is one element of physical condition or explosive power that greatly affects the results of the squat-style long jump jump. Speed and power are factors in determining jump distance. To increase energy when jumping, muscle strengthening exercises are needed. One way to train strength is by training up and down stairs.

In the process of athletic extracurricular activities, especially the long jump number, teachers or coaches are required to be able to modify the training program so that students can feel comfortable and students are interested in learning the material provided. The more students are interested in learning the long jump, the easier it will be for students to understand the correct technique given by the teacher, so that later the jump achievement of each student can be optimized. 
Coaches play a very important role in improving the results of the long jump athletic extracurricular student achievement. The role of the coach in the long jump athletic sport is also an important element because a good training program will increase the enthusiasm of students in participating in long jump athletic extracurricular activities. Thus, students' insight into long jump athletics is wider and can be useful for themselves and others. In addition to the role of coaches and good training methods, improving achievement must require good management and extracurricular management so that the implementation that has been planned will run according to what is to be achieved.

The training program provided by the teacher does not have a target for student achievement to excel, here the teacher only teaches materially and does not practice it carefully, it can be said if students cannot do the long jump properly and correctly the teacher just leaves it without any additional action or exercise that can improve students' ability to perform long jump squat style.

The lack of students' ability in the squat style long jump becomes a challenge for teachers/coaches that must be answered through concrete actions. The actual action in question must be both in teaching activities and in planning, developing and evaluating the teaching of the training program itself. With this, the researcher will conduct an experiment with an exercise program up and down stairs, this may be successful in increasing the results of the squat long jump. The movement up and down stairs is also known as the step-in movement. This type of movement is very good for training the leg muscles to be stronger and able to overcome many obstacles. How to do this step-in movement by lifting one leg and then lifting the other leg with sequential and fast movements.

Based on the background of the problem and the observations, the authors propose the title of the research, namely "The Effect of Up and Down Ladder Exercises on the Results of the Squatting Style Long Jump on Extracurricular Participants at Sma Negeri 6 Bengkulu Selatan"

\section{METHODS}

The type of research used is experimental. According to the opinion (Sugiyono, 2018), the experimental research method is a research method used to find the effect of certain treatments on others under controlled conditions. The experimental method has various experimental designs that can be used in research.

The design used in this study is the one-group pretest-posttest design, Sugiyono, (2018) states that the one-group pretest-posttest design type is this type of research where there is a pretest before being treated and there is a posttest after being treated. This design requires one group to be selected according to the research needs.

This design will give two tests to the extracurricular participants of SMA Negeri 6 Bengkulu Selatan. Before being given treatment, the extracurricular participants of SMA Negeri 6 Bengkulu Selatan did a pre-test in the form of a squat long jump . After conducting the pre-test, the researcher gave treatment to the students in the form of an exercise program. The treatment given was up and down stairs exercise after being given treatment the experimental group was given a post-test in the form of long jump squat style $\left(0_{1} 0_{2}\right)$.The research process requires a population as a data source and requires the entire material to be studied. 
According to Sugiyono (2018) Population is a generalization area consisting of: objects/subjects that have certain qualities and characteristics determined by researchers to be studied and drawn conclusions. In this study, the population used was 25 students who took the long jump extracurricular at SMA Negeri 6 Bengkulu Selatan.The variable in this study is the independent variable consisting of exercises up and down stairs $\mathrm{X}$, the dependent variable is the result of the squat style long jump.The data collection technique in this study used the long jump test. The data collected in this study were pree test and posttest, namely before being given treatment and after being given treatment.

Data analysis was carried out by comparing the post-test, this analysis using the one sample test to determine the average (one sample test) with this test it will be known whether there is an influence between the average value of the pre-test and post-test experimental class. Before the one sample test was carried out, the normality test was first tested to find out whether the experimental class was normally distributed or not. If the class is normally distributed, then the statistics used are statistical parameters. Meanwhile, if using non-parameter statistics, then the class does not have to be normally distributed. Similar sample t test means that the power distribution being compared comes from the same group of subjects.

\section{RESULTS}

Based on the results of the squatstyle long jump test, the pretest and the posttest in extracurricular participants at SMA N 6 Bengkulu Selatan on each test that has been carried out. For more details can be seen in the following descriptive statistics:

\section{Descriptive pretest statistics}

The initial long jump test results obtained a minimum value of 2.00 , a maximum of 3.90, an average of 2.8, and a standard deviation (standard deviation) of 0.55 . For more details, it can be seen in the histogram as follows:Posttest Descriptive Statistics

After giving the exercise of going up and down the stairs to the extracurricular participants, the data collection of the long jump test results was carried out again. It was found that the minimum score on the final test was different where there was an increase in after being treated with up and down stairs. The results of the long jump final test can be depicted on the frequency distribution histogram as follows:

\section{Prerequisite Test}

\section{Normality Test}

Calculation of normality using the lilefors formula the results obtained are:

Tabel 1.

\begin{tabular}{lllllll}
\hline $\begin{array}{l}\mathbf{N} \\
\text { o }\end{array}$ & $\mathbf{N}$ & Pre-Test & Final Test & Note: \\
\hline & & $\mathrm{L}_{\mathrm{o}}$ & $\mathrm{L}_{\mathrm{t}}$ & $\mathrm{L}_{\mathrm{o}}$ & $\mathrm{L}_{\mathrm{t}}$ & $\begin{array}{l}\text { Distribu } \\
\text { tion }\end{array}$ \\
\hline 1 & 2 & 0.13 & 0.17 & 0.15 & 0.1 & Normal \\
& 5 & 63 & 3 & 62 & 73 & \\
\hline
\end{tabular}

From the table above, it is known that $\mathrm{L}_{\mathrm{o}}<\mathrm{L}_{\mathrm{t}}$, means that the data taken from one experimental group under study have data that are normally distributed. 2. Homogeneity Test

The result of the calculation of the variance of the initial test $(\mathrm{X})$ is $(0.55)$, while the variance of the final test $(\mathrm{Y})$ is (0.71).

From the calculation above, the value is 1.29 while the value at the significant level is 1.291 .98 . This means that there is no difference between each variable or the variance is homogeneous. 


\section{Hypothesis Test}

In analyzing the hypothesis test, the post-test results of the experimental group are needed. The processing of data analysis was carried out by calculating the effect of the long jump exercise on the count range (pre-test) and (post-test) of the experimental group.

It is known that $\mathrm{Ha}$ is acceptable because 5,664 2,064. It can be concluded that the hypothesis states that there is an effect of training up and down stairs on the results of the squat-style long jump in extracurricular participants at SMA Negeri 6 Bengkulu Selatan

\section{DISCUSSION}

In this study, the aim of this study was to determine the effect of up and down stairs training on the results of the squat-style long jump on extracurricular participants at SMA Negeri 6 Bengkulu Selatan. This type of research is experimental where the research process is carried out for 16 meetings, by taking an initial test before being given training treatment and after being given treatment. Based on theoretical studies and statistical calculations with reference to the conclusions of the analysis carried out.

According to the results of the research that has been done that overall that the results of the long jump on extracurricular participants at SMA Negeri 6 Bengkulu Selatan before being given the treatment of training up and down stairs, there were 25 students, namely 8 students still had a poor category, 17 students had a sufficient category, and 2 students have good category. However, after being given the training program, 8 students were in sufficient category, 7 students were in good category, and 9 students were in very good category.
Exercise is a process of consciously improving the quality of athletes to achieve maximum performance by being given physical and mental loads on a regular, directed, gradually increasing and repeated time. This increase in training, of course, must also be adjusted to the type of competition that each athlete will participate in. According to Sugihartono, et al (2017) The exercise of going up and down stairs can also be called the Harvard step, this up and down stairs exercise aims to increase the speed element of strength in physical condition. because the elements of speed and strength are part of the fundamentals of the long jump. In addition, going up and down the stairs aims to increase the endurance of the leg muscles.

From the results of the pre-test that the long jump test results were still low so that the sample ran the exercise program for 1 month, namely 16 meetings, after that the post-test final test was carried out again, there was an increase, from the results of the pre-test and post-test data there were an average increase of . Research shows that the exercise of going up and down stairs has an effect on the results of the squat-style long jump in extracurricular participants at SMA Negeri 6 Bengkulu Selatan.

After testing the hypothesis, the results of the analysis of the calculation of the results of the squat-style long jump stated that there was a significant effect with the provision of up and down stairs training on the results of the squat-style long jump.

It can be concluded from the analysis above that by providing training up and down stairs will have a very large effect in improving the results of the squat style long jump. 


\section{CONCLUSIONS}

Based on the data analysis of the research results that have been described in the previous chapter. that the results of data collection and statistical analysis results of up and down stairs training on the long jump results in the pre-test as far as 3.90 meters and the closest 2.00 meters so that the average long jump result is 2.80, after the pre-test data is taken, the sample carries out an exercise program for 1 month ago, after that, the post-test final test was carried out again and got the furthest distance of 4.50 meters and the nearest 2.60 meters with an average value of 3,496, from the results of the pretest and posttest data there was an increase in the average result of 0.69 .

This means that it can be expected as a reference in providing treatment to students in improving the long jump results. The trainer does not need to be afraid to do the "Up and Down Ladder" Exercise as one of the programs in power training. Before giving the "Up and Down Ladder" Exercise, one must master a systematic training program, so that it is measured according to the ability of students so that adaptation of physical exercise is optimal and can improve student achievement.

\section{SUGGESTION}

Based on the conclusions above, there are several suggestions that can be submitted, namely:

1. For long jump extracurricular trainers, it is hoped that they can provide the right exercises and materials according to the preparation of an effective training program with the hope that students have good long jump results.

2. For athletes / students participating in extracurricular activities, in order to be serious in doing and improving them by means of regular exercises, one of which is using up and down stairs exercises in order to get more optimal results.

3 . For other researchers or readers who want to do further research, please make this research as information material, and can research with a wider number of samples and populations as well as different exercise variables so that exercises to improve long jump results can be identified more broadly.

\section{REFERENCES}

Alexon. (2018). Statistic Untuk Penelitian Pendidikan. Bengkulu: Fkip Universitas Bengkulu.

Akhmad,Dkk (2019). Keterampilan Lompat Jauh Untuk Gaya Jongkok, Jurnal Unj.Segar, 7(3).

Aprianto,Willi. (2019). Implementasi Ekstrakurikuler Atletik Nomor Lompat Jauh Pada Sekolah Menengah Pertama Negeri Kota Bengkulu, Jurnal Kinestetik, 3(2) E-ISSN 2685-6514.

Aziz Muhammad. (2019). Perbedaan Pengaruh Latihan Pliometrik dan Kecepatan Lari Terhadap Kemampuan Lompat jauh Gaya Jongkok. 2(2) E-342-462.

Bahagia, Yoyo. (2017). Media Dan Pembelajaran Penjas Bandung: Abdul Jabar

David,Sahari Muhammad. (2014). Pengaruh Latihan Naik Turun Bangku Terhadap Hasil Lompat Jauh Gaya Jongkok Pada Siswa Putra Kelas V Sd Negeri 08 Suka Maju Makmur Kecamatan Putrid Hijau Kabupaten Bengkulu Utara. Jurnal Kinestetaik.

Jarver,Jess. (2008). Pengaruh Latihan Naik Turun Bangku Terhadap Hasil Lompat Jauh Gaya Jongkok Pada Siswa Putra Kels VIII Smp N 
02 Negeri Labuhan. Jurnal Unila s2362/313.

Jufri, Muhammad. (2019). Peningkatan Kemampuan Lompat Jauh Melalui Metode Lompat Books. Jurnal Unm 5(7).

Kurniawan,Feri.

(2017).Pintar

Pengetahuan Olahraga Jakarta Timur: Lascar Aksara.

Maijun. (2017). Peningkatan Kemampuan

Teknik Dasar Lompat Jauh Gaya

Jongkok Siswa Sekolah Dasar

Melalui Strategi Modifikasi,

Jurnal Uin.Suska, 3(3).

Ridwan, M., \& Sumanto, A. (2017).

Kontribusi Daya Ledak Otot

Tungkai, Kecepatan dan

Kelentukan dengan Kemampuan

Lompat Jauh. Jurnal Performa

Olahraga, 2(01), 69-81.

Sugiyono. (2014).Metode penelitian Kuantitatif Dan R\&D. Bandung: ALFBETA,CV

Sugihartono, Dkk. (2017). Perbedaan Latihan Naik Turun Tangga Tunggal (Satu Tangga) Dengan Naik Turun Tangga Jamak (Enam Tangga) Terhadap Kemampuan Lari Sprint 60 Meter Siswa Kelas V Sd Negeri 69 Kota Bengkulu,
Jurnal Kinestetik, 1(1).ISSN 2477-331.

Wiarto, Giri. (2017). Atletik Yogyakarta: Graha Ilmu.

Zainuri, K. (2020). Peningkatan Hasil Pembelajaran Lompat Jauh Melalui Pendekatan Bermain Longu pada Siswa Kelas IV SDN 37 Ampenan. Jurnal Paedagogy, 7(1), 35-42. 